DOI 10.37882/2500-3682.2020.07.13

\title{
ФОРМИРОВАНИЕ НАВЫКОВ СОЦИАЛЬНОГО ВЗАИМОДЕЙСТВИЯ У МЛАДШИХ ШКОЛЬНИКОВ С УМСТВЕННОЙ ОТСТАЛОСТЬЮ
}

\section{THE FORMATION OF SOCIAL INTERACTION SKILLS IN VISUALLY IMPAIRED PRIMARY SCHOOL STUDENTS WITH MENTAL RETARDATION \\ V. Kudryavtsev \\ L. Karaseva}

Summary: The article considers approaches to the formation of social interaction skills in visually impaired primary school students with mental retardation. Based on the analysis of theoretical sources, the features of children's behavior in the team, the skills of social interaction are considered. The possibilities of using gaming technologies in the process of working with younger students with mental retardation are studied. The results of testing a psychocorrectional program for the formation of social interaction skills in these children are presented.

Keywords: visually impaired primary school students; mental retardation; social interaction; adaptation; conflict; behavior style.

\author{
Кудрявцев Владимир Александрович \\ К.nсх.н., дочент, Нижегородский государственный \\ педагогический университет им. К. Минина, \\ Нижний Новгород \\ kudvol@yandex.ru \\ Карасева Лидия Александровна \\ Нижегородский государственный педагогический \\ университет им. К. Минина, Нижний Новгород \\ karasevalidiya95@gmail.com
}

Аннотация: В статье рассмотрены подходы по формированию навыков социального взаимодействия у слабовидящих младших школьников с умственной отсталостью. На основе анализа теоретических источников рассмотрены особенности поведения детей в коллективе, навыки социального взаимодействия. Изучены возможности использования игровых технологий в процессе работы с младшими школьниками с умственной отсталостью. Представлены результаты апробации психокоррекционной программы по формированию навыков социального взаимодействия у данных детей.

Ключевые слова: слабовидящие младшие школьники; умственная отсталость; социальное взаимодействие; адаптация; конфликт; стиль поведения.

\section{Введение}

A даптированная основная общеобразовательная программа в соответствие с Федеральным государственным образовательным стандартом образования обучающихся с умственной отсталостью (интеллектуальными нарушениями) главными критериями работы с такими детьми определяет развитие жизненных компетенций, навыков социального взаимодействия и повышение адаптивных возможностей таких детей в рамках социального взаимодействия.

Требования ФГОС ставят перед современной школой сложную задачу - создание оптимальных условий для всестороннего развития личности обучающегося, при этом большое внимание необходимо уделять развитию в социальной компетентности каждого ребёнка для его дальнейшей успешной социализации в обществе. Это касается в равной степени как обычных учащихся, так и детей с особыми образовательными потребностями.

Согласно статистическим данным количество детей с тяжелыми и множественными нарушениями в развитии (TMHP) ежегодно увеличивается. Эта общемировая тенденция актуализировала потребность в создании развернутой и качественной системы помощи этой кате- гории детей и их ближайшему социальному окружению [5]. Развитию навыков социального взаимодействия слабовидящих младших школьников с умственной отсталостью в последнее время стало уделяться повышенное внимание, что обусловлено кардинальными изменениями государственной политики в сфере инклюзивного образования, предполагающей включение обучающихся с умственной отсталостью в общеобразовательную среду массовой школы.

Несформированность навыков социального взаимодействия у детей с умственной отсталостью, отягощенной нарушениями зрения, ставит перед ними серьезные препятствия личностного развития, значительно осложняет адаптацию таких детей. В особенности это актуально на первых этапах обучения ребенка в начальной школе, поскольку появление в это время конфликтов во взаимоотношениях со сверстниками в дальнейшем будет только усугубляться. Поэтому необходимость целенаправленной работы с детьми в период их обучения в начальной школе, особенно в неблагоприятных и трудных для них условиях, на данном этапе генезиса обладает большой значимостью.

Актуальность проблемы формирования навыков социального взаимодействия у слабовидящих младших 
школьников с умственной отсталостью обусловлена также необходимостью поиска методов и приемов для эффективного преодоления дезадаптированности детей, оптимизации их отношений с педагогами и сверстниками.

\section{Формулировка шели статьи}

Полноценное развитие личности ребенка тесно связано с формированием у него адекватного уровня притязаний, осознания себя, своего «Я», объективной самооценки. В данной связи С.Д. Забрамная отмечает, что детям с умственной отсталостью отягощенной нарушением зрения, характерна заниженная самооценка, непоследовательность действий и неадекватность поведения, они не могут осознать свою роль в социальном взаимодействии и поэтому не понимают, как к ним относятся сверстники и взрослые [4].

Проблема формирования личности умственно отсталого школьника, навыков социального взаимодействия, является на сегодняшний день наименее разработанной. Так как таким детям свойственна замедленность и общее несовершенство усвоения определенных закономерностей и понятий, слабость мыслительных процессов, они довольно поздно и с трудом осваивают моральные ценности и нравственные категории, плохо или совсем не разбираются в вопросах общественного устройства. Понимание детей о том, что хорошо, а что плохо, в младшем школьном возрасте довольно несовершенны и поверхностны. Моральные ценности дети усваивают со слов родителей, педагогов, в некоторых случаях - из фильмов, при этом они редко способны действовать адекватно, в соответствии с этими нормами, равно как и использовать их, в соответствие с каждой конкретной ситуацией. В сложных ситуациях дети просто теряются и замыкаются в себе, из-за чего совершают неадекватные поступки, часто поддаются чужому влиянию.

В процессе работы с умственно отсталыми младшими школьниками педагог сталкивается с серьезными проблемами. Процесс образования внутриколлективных связей и межличностное взаимодействие осложняется неумением детей вникнуть в проблемы товарища, неспособностью к соучастию, к установлению коммуникативных навыков. Грубые нарушения высших психических функций, несформированность важнейших качеств личности у детей с умственной отсталостью значительно сужают круг их мировоззрения, связей, интересов, сфера их действий ограничена бытовой направленностью и строгой ситуативностью. Если у детей и появляются какие-то привязанности среди сверстников, то они носят поверхностный, неустойчивый характер, длительные дружеские связи умственно отсталые младшие школьники не формируют и не поддерживают. Качественное своеобразие структуры дефекта при умственной от- сталости, отличающее стойкостью, в совокупности с нарушением зрения, слабость когнитивных функций, пониженная самооценка и самокритичность, слабость волевых процессов, отсутствие самостоятельности и социальной активности, значительно затрудняют процесс социального взаимодействия у таких детей. В то же время, как утверждает И.М. Бгажнокова, все указанные нарушения поддаются постепенной корректировки в процессе целенаправленного воспитания и обучения [2].

Правильно выбранный метод коррекции и подход в воспитании слабовидящих младших школьников с умственной отсталостью помогает как сформировать правильное и устойчивое мировоззрение у детей, добиться быстрой адаптации в новых для них условиях, развить навыки социального взаимодействия.

\section{Из^ожение основного материала статьи}

Формирование навыков социального взаимодействия у слабовидящих младших школьников с умственной отсталостью предполагает обязательное формирование у них таких качеств, как самостоятельность, активность, желание создавать межличностные связи. В данной связи Л.М. Рышкова выделяет игру как действенное средство коррекции психофизического развития таких детей, поскольку в процессе игры дети раскрепощаются, активизируют свои скрытые способности, игра помогает развитию волевой сферы, коммуникативных процессов. В особенности этому способствуют сюжетноролевые игры, которые предполагают непосредственный контакт детей друг с другом [6].

Л.Б. Баряева предлагает использовать сюжетно-ролевые игры как действенный способ социализации умственно отсталых школьников [1].

А.В. Гордеева предлагает такую организацию работы с детьми, при которой возможно оптимальным образом регулировать взаимоотношения детей в коллективе, направлять и помогать им, тем самым обеспечить положительную эмоциональную атмосферу в классе, способствовать активному общению учеников друг с другом. Игра, в любой своей форме, является исключительным по своему потенциалу и продуктивности методом развития навыков социального взаимодействия слабовидящих школьников с умственной отсталостью, поскольку в игровой ситуации деятельность детей приобретает более глубокий личностный подтекст, продуцирует произвольное познание ребёнком окружающей действительности, основанное на интересе и желании узнавать новое, понимать окружающие явления и процессы [3].

В ходе занятий со слабовидящими младшими школьниками с умственной отсталостью навыки сглаживать конфликты, легко и безболезненно решать межличност- 
ные проблемы должны подаваться детям и изучаться более глубоко и всесторонне, поскольку от этого зависит будущая адаптация ребенка к современным реалиям времени.

В формате заявленной проблемы была разработана и апробирована программа формирования навыков социального взаимодействия у слабовидящих младших школьников с умственной отсталостью. В программе приняли участие 12 обучающихся 2,3 и 4 классов ГКОУ «Школа-интернат №2» г. Нижнего Новгорода. У детей диагностирована умственная отсталость легкой степени в совокупности с нарушением зрения.

Программа психокоррекционной работы была построена на основе стимуляции и фиксации ощущения и осознания ребенком себя, своего «Я», как субъекта социума. В процессе взаимодействия слабовидящие младшие школьники с умственной отсталостью начинают постепенно находить в себе положительные качества, ценить себя как личность, у них расширяются представления о социальном взаимодействии, приходит понимание своей роли в коллективе.

В программу были включены элементы игротерапии, арттерапии, музыкальное сопровождение, сюжетно-ролевые игры и психодраматические упражнения, которые распределялись равномерно в течение всего периода проведения коррекционных занятий. Коррекционная программа состояла из следующих основных этапов:

Первый этап - адаптация ребенка к новым условиям. На данном этапе дети знакомились друг с другом, устанавливался положительный настрой на дальнейшую работу. На втором этапе формировалось адекватное отношение обучающихся друг к другу. Дети коллективно обсуждали игры и задания, в ходе диалогического общения формировались навыки анализирования состояния другого человека, самоанализа. На третьем этапе осуществлялось формирование у младших школьников адекватного отношения к себе, самооценки, социальной значимости и самостоятельности. Дети учились прощать и просить прощения в сложных конфликтных ситуациях. На четвертом этапе школьников обучали навыкам социально - адекватного поведения, межличностного общения и бесконфликтного поведения в социальной среде. На последнем, пятом этапе подводились итоги работы, обобщались полученные детьми знания и опыт.

Кроме занятий в классе, младшие школьники получали домашние задания, также направленные на развитие социального взаимодействия. Задания давались из расчета совместной работы детей и родителей.

После апробации психо-коррекционной программы была проведена повторная диагностика навыков со- циального взаимодействия у слабовидящих младших школьников с умственной отсталостью.

Первая методика, по которой проводилась диагностика - рисованный апперцептивный тест Г. Мюррея. Направлен на исследование внутренних движущих сил личности - ее конфликтов, переживаний, движущих мотивов поведения, интересов и влечений. В результате, у 39\% испытуемых экспериментальной группы появилась новая потребность, которой не было до проведения с ними психо-коррекционной работы - потребность в аффилиации, т.е. потребность общаться на равных со сверстниками, создавать доверительные, эмоционально значимые отношения, в контрольной группе такой потребности выявлено не было. У з3\% испытуемых экспериментальной группы повысилась потребность в достижении, т.е. школьники стремятся чего-то достичь, преодолеть препятствия, хотят реализовать свои способности и тем самым повысить самоуважение и уважение сверстников.

Потребность в независимости, автономии, в желании действовать самостоятельно в соответствие со своими убеждениями показали 30\% испытуемых экспериментальной группы и только 9\% контрольной.

По методике Р. Жиля исследовались межличностные отношения, которые показали положительную динамику. По шкале «общительность» в ЭГ результаты повысились до 65\%, в КГ - результаты средние (40\%). Данная динамика подтверждает предыдущие результаты и показывает, что школьники стремятся к общению, взаимодействию, проявляют инициативу и активный интерес к завязыванию новых отношений. В КГ группе результаты ниже средних, дети с трудом шли на контакт, не включались в совместные игры. По шкале «любознательность» результаты также повысились - 50 \% у испытуемых ЭГ и только 12\% в контрольной группе. После коррекционных занятий у испытуемых экспериментальной группы заметно вырос интерес к получению знаний, в целом, к учебному процессу.

По шкале «социальная адекватность поведения» после проведенных коррекционных занятий в ЭГ результаты значительно выше, в сравнении с констатирующим этапом (72\%). В контрольной группе результаты на низком уровне (32\%). Это указывает на дезадаптированность испытуемых, неумение приспособиться к окружающей обстановке, школьники не могут противостоять жизненным трудностям, что может проявляться неадекватными реакциями - излишней скрытностью или наоборот, агрессией». То есть у младших школьников, не участвовавших в коррекционной программе, остались те же негативные черты, которые были выявлены на констатирующем этапе исследования. 
По шкале «стремление к замкнутости, отгороженности» показатели в экспериментальной группе существенно снизились. Их значение минимально (5\%) против 72\% на констатирующем этапе. Это говорит о том, что обучающиеся уже не избегают общения, наоборот, активно включаются в совместные игры и мероприятия. В КГ результаты остались на том же уровне, что и на этапе первичной диагностики.

По результатам диагностики социализированности личности младших школьников (методика М.И.Рожкова) в экспериментальной группе высокий уровень показали $42 \%$, средний - 33\%, низкий 25\% обучающихся. Данные результаты существенно превосходят показатели контрольной группы. В ЭГ дети показали более высокую способность адаптации к социальным условиям, самоконтроль, активность и самостоятельность в поведении.

Способы поведения в конфликте исследовались по опроснику К. Томаса в адаптации Н.В. Гришиной. Результаты показали, что большинство испытуемых ЭГ (68\%) выбрали наиболее оптимальный стиль поведения в конфликте - сотрудничество. На констатирующем данный стиль поведения в конфликте не выбрал ни один испытуемый. На втором месте был выбран стиль «компромисс» (52\%). Результаты исследования детей контрольной группы показали, что большинство из них выбрали стили «приспособления» и «избегания» конфликта. Ис- пытуемые не стремились ни к сотрудничеству, ни к достижению собственных целей, были склонны уступать в конфликтах, сглаживать острые углы, избегать открытого столкновения или вообще конфликтной ситуации.

\section{Выво $\Delta ы$}

Таким образом, проведенная психокоррекционная программа формирования навыков социального взаимодействия у слабовидящих младших школьников с умственной отсталостью показала следующие положительные результаты:

- существенно повысились навыки социальной адекватности поведения, способность противостоять конфликтным и проблемным ситуациям;

- обучающиеся охотно заводят новые контакты, вступают во взаимодействие со сверстниками;

- значительно повысилось положительное отношение к педагогу, интерес к учебному процессу;

- в целом уровень социальной адаптации слабовидящих младших школьников с УО после проведения коррекционных занятий вырос как по отношению к сверстникам, так и к педагогам.

Кроме того, дети показали более высокую способность адаптации к социальным условиям, активность и самостоятельность в поведении, старались придерживаться принятых норм поведения.

\section{ЛИТЕРАТУРА}

1. Баряева Л.Б. Обучение сюжетно-ролевой игре детей с проблемами интеллектуального развития: учебно-методическое пособие / Л.Б. Баряева, А. Зарин . СПб.: Изд-во РГПУ им. А.И. Герцена: Изд-во «Союз», 2011. - 414 с.

2. Бгажнокова И.М. Практикум по психологии умственно отсталого ребёнка. М.: МГЗПИ, 2013. - 93 с.

3. Гордеева А.В. Реабилитационная педагогика: Учебное пособие для студентов педагогических вузов и колледжей. М.: Академический проект, 2005. - 320 c.

4. Забрамная С.Д. Психолого-педагогическая диагностика умственного развития детей: учеб. для студентов дефектол. фак. и ун-тов / С. Д. Забрамная. М.: Просвещение; Владос, 1995. - 112 с.

5. Ольхина Е.А., Новикова Ю.А. Анализ проблемных зон в реализации специальной индивидуальной программы развития //Евразийское Научное 0бъединение. 2019. № 10-6 (56). С. 500-503.

6. Рышкова Л.М. Реабилитационные возможности игры в работе социального педагога с детьми с особыми образовательными потребностями // Специальное образование: материалы Х международной научной конференции 23-24 апреля 2014 г. / Под общ. ред. проф. В.Н. Скворцова. СПб.: ЛГУ им. А.С. Пушкина, 2014. Т. 2. С. 258-260.

с Кудрявцев Владимир Александрович (kudvol@yandex.ru), Карасева Лидия Александровна (karasevalidiya95@gmail.com). 